\title{
Seweryn Blandzi, Między aletejologia Parmenidesa a ontoteologią Filona, IFiS PAN, Warszawa 2013; dodruk 2017, ss. 352.
}

DOI: http://dx.doi.org/10.12775/RF.2017.030

Bez żadnej przesady można powiedzieć, że Seweryn Blandzi w pracy Między aletejologia Parmenidesa a ontoteologia Filona zaoferował rozstrzygające, niekiedy wręcz definitywnie, wykładnie najtrudniejszych z kwestii poruszanych $\mathrm{w}$ tekstach antycznych, kwestii szeroko dyskutowanych i rozmaicie interpretowanych, a mógł je dać, stosując perfekcyjnie opanowane instrumentarium: lingwistykę. Potrafił wychwycić swoistości języka greckiego, niezauważane, a w każdym razie nieuwzględniane konsekwentnie przez najlepszych znawców, które pozwoliły mu dotrzeć do właściwego, możliwego do zaakceptowania sensu miejsc zawiłych, odczytywanych często jako paradoksy, stwierdzenia - wydawałoby się - sprzeczne ze zdrowym rozsądkiem. Podstawowe znaczenie miało ujawnienie, tak na podstawie przebadanej literatury przedmiotu (Ch. Kahn, słowniki), jak własnych poszukiwań, w tym konfrontacji z innymi językami, i skrupulatne rozgraniczenie rozmaitych funkcji (bo unika raczej mówienia o "znaczeniach") słowa, które stanowi, by tak rzec, duszę mowy greckiej, a występuje w wielu formach, w tym najbardziej doniosłej dla filozofii postaci participium $\tau o ̉$ őv, mianowicie verbum عĩvol.

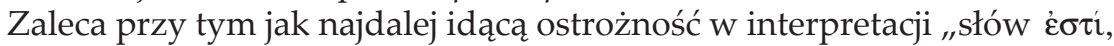
Eiv $\alpha 1$, ćov oraz ich negacji, które w użyciu greckim odgrywają rolę wielofunkcyjną (werytatywna, predykacyjna, znaku tożsamości, znaczenia egzystencjalnego)", sam starając się ściśle przestrzegać tych różnic.

I właśnie to najważniejsze narzędzie, ten niezbędny potem przy docieraniu do jądra rozpatrywanych, a zamkniętych dla wielu kwestii klucz tworzy sobie w pierwszych paragrafach rozdziału 1, dochodząc, jakie intuicje wiązali Grecy z imiesłowem őv. Nie tylko uwzględnia przy tym sądy dawnych myślicieli (oprócz, ma się rozumieć, Platona i Arystotelesa, stoicy, sofiści, Seneka, Plotyn, Proklos, Simplikios, Jan Damasceński), ale i licznych nowożytnych polskich i obcych filologów, filozofów, logików (Spinoza, Hegel, Heidegger, Husserl, Lotze, Rickert, Anscombe, Bolzano, Frege, Woleński, Łukasiewicz, Komornicka, Snell, Beaufret), 
nieraz z nimi polemizując. Dwie z wykrytych funkcji czasownika cĩval, a rzutujących na jego formę imiesłowowa, okazują się szczególnie doniosłe dla zrozumienia enigmatycznie niekiedy brzmiących wywodów Parmenidesa i Gorgiasza, którymi się Blandzi kolejno zajmie: funkcja werytatywna i predykatywna.

Pierwsza znajduje zastosowanie od razu przy prowadzonej już w ramach rozdziału 1 analizie fragmentów poematu Parmenidesa o zrekonstruowanym tytule $O$ naturze (bytu) Prawdy. Podkreślają to tytuły paragrafów: "Droga ku światłu Prawdo-bytu”, "Odpomnienie

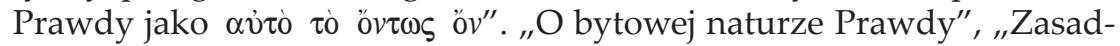
nicza funkcja werytatywna czasownika عivaı", "Parmenidejska droga Prawdy", "Aleteizm Parmenidesa”, „Od afirmacji do charakterystyki bytu Prawdy". Sens werytatywny słowa "Będące” (ov) i jego wyróżnione miejsce $\mathrm{w}$ grece dokumentuje autor tak na podstawie leksykonów (J. E. Powell), jak fundamentalnego dla kwestii lingwistycznych związanych z czasownikiem eivo dzieła Kahna (The Verb «Be» in Ancient Greek), umacniając wnioski niezwykle celnie dobranymi przykładami oryginalnych autorów. Druzgocących argumentów przeciwko tym, którzy wszędzie pod o]n chcieliby podstawiać "twardy rzeczownik" byt, dostarcza, cytując Herodota, choćby w tym jednym zdaniu o dowiadywaniu się

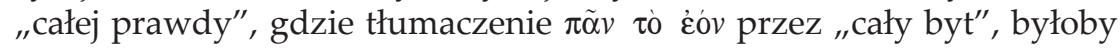
oczywiście absurdalne.

Są wśród fragmentów Parmenidesa takie, z których dotychczasowych, częstokroć rozbieżnych interpretacji trudno wybrać zadowalającą. Te szczególnie wnikliwie Autor analizuje. Nad każdym takim przypadkiem powinien się czytelnik z uwagą pochylić, nie przebiegając analiz tylko pobieżnie. Uderza subtelne rozszczepianie niuansów znaczeniowych pojedynczych wyrazów, jak np. słówka $\omega$ ` (nie tylko "że”, ale i „jak"), nade wszystko zaś słówka „,jest”, które oprócz dominującego sensu werytatywnego wyrażać może także np. potencjalność („,nie jest «możliwe»"), podobnie wnikliwe rozumienie form negatywnych: $\mu \eta$ ' reguł składniowych, niekiedy specyficznie stosowanych przez Parmenidesa (np. ह̌ $\sigma \tau \mathrm{w}$ roli podmiotu), wreszcie ocena i wybór najodpowiedniejszej lekcji przekazów (Prawda "przekonująca”, "doskonała”, lub „świetlista”).

Godna uwagi też jest konfrontacja ze sobą różnych miejsc poematu, np. powiązanie zakończenia z początkiem i z tytułem, co pozwala rozwiązać pewien dylemat: „Znajdujemy tym sposobem merytoryczny podmiot (poszukiwany bezskutecznie przez wszystkich interpretatorów) już w zakończeniu prologu: podmiotem tym jest Prawda". A jedną z najbardziej kontrowersyjnych i szeroko dyskutowanych tez Parmeni-

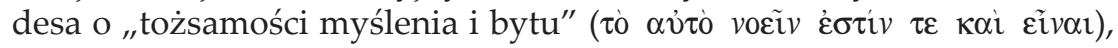
Blandzi objaśnia prosto i jakże przekonująco: „tylko to, co jest (sc. praw- 
dą), może być pomyślane, i tylko wtedy, gdy przedmiotem myśli jest Prawda, zachodzi tożsamość (= adekwacja) myślenia i bytu". Decydującą rolę odegrało tu - jak widzimy - uwydatnienie roli عĩval w stwierdzaniu prawdy, z zawieszeniem dominującego wciąż znaczenia egzystencjalnego, co uczony wyraził w innym miejscu ogólnie: „należy zwrócić uwagę na funkcję centralną słowa «jest», właśnie werytatywną eliminując tym samym posługiwanie się znaczeniem «istnieć»". Wagę tego odkrycia trudno przecenić.

$\mathrm{W}$ prowadzonej w obszernym rozdziale 2 analizie zachowanych w dwu wersjach fragmentów traktatu Gorgiasza O niebycie, czyli o naturze, walczy znów nasz autor z przemożnym w przekładach i komentarzach panowaniem treści egzystencjalnych, które $z$ wielu wypowiedzi filozofa z Leontinoi (Blandzi woli to określenie od deprecjonującego cokolwiek „sofista” ) czynią nonsensy. Dotyczy to już pierwszej tezy: ov̉ó́v

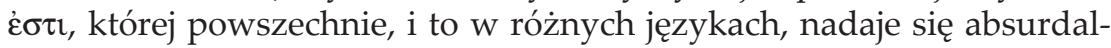
ny sens: „nic nie istnieje”. Autor wykazuje, że taki przekład jest nie do przyjęcia, choćby z tego względu, że wymusza naruszenie zasad gramatyki w następującej zaraz potem tezie drugiej. Poprzednikowi okresu warunkowego ,jeśli zaś istnieje” brak podmiotu; nie może być nim ov̉ó́v z tezy pierwszej, a wprowadzanie, jak czynią niektórzy, zaimka „coś” jest nieuprawnione. Nawet wydawcy czują się zmuszeni do wprowadzenia koniektury (zaimka ti) w tekście oryginału, co nasz uczony uważa za zbyteczne, a w roli podmiotowego „coś" do orzeczenia „istnieje”, wprost mylące.

Rozprawiając się z bezzasadnie wprowadzanym pojęciem istnienia, poddaje autor tytułem przykładu krytycznej analizie słynną maksymę Protagorasa, którą przytacza w następującym stereotypowym przekładzie: „Wszystkich rzeczy miarą jest człowiek, istniejących - że sa, nieistniejących [?] - że nie istnieją". Człowiek ma tu jakby wyrokować o istnieniu, jako swoista "miara rzeczy”, którą nie wiadomo, jak mamy rozumieć. A jakkolwiek rozumiane „mierzenie” czegoś, co nie istnieje, w ogóle trudno pojąć. Blandzi podnosi ważny lingwistyczny szczegół,

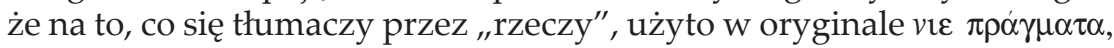
lecz $\chi \rho \eta \mu \alpha \tau \alpha$, mające znaczenie "rzeczy potrzebne, użyteczne”. Wykorzystując to, a nadto $\mathrm{w}$ miejsce egzystencjalnego wprowadzając predykatywne rozumienie o $v \tau \alpha$, daje swój przekład, klarowny i instruktywny: „Miarą użyteczności wszelkich rzeczy jest człowiek, tych będących takimi, że [nimi] sa, a nie będących takimi, że [nimi] nie są".

$W$ następujących dalej, wnikliwie roztrząsanych przez uczonego wywodach Gorgiasza, pokazuje on z całą finezja, jak egzystencjalne

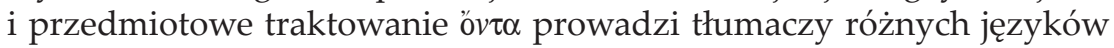
na manowce. Nie tylko wydobywają oni z oryginału myśli, których tam nie ma, i to myśli trudne do zaakceptowania przez zdrowy rozsądek, ale wręcz zmuszeni są zawieszać reguły gramatyki. Tłumacz angielski 
W. S. Hett np., obstając przy „istnieniu bytu”, bezprawnie oddaje pluralis $\tau \tilde{\omega} v$ òv $\tau \omega v$ przez singularis Being, "sugeruje więc, jakoby zdanie mówiło o zwalczaniu przez Gorgiasza twierdzeń o «Bycie» jako czymś jednym, podczas gdy on wykazywał tylko, że atrybuty, jakie przypisywano rzeczom ( $\tau \dot{\alpha}$ ovv $\tau)$, wykluczają się jedne z drugimi". Tłumacz ignoruje także oczywistą dla grecysty zasadę, że do podmiotu w neutrum plurale stosuje się orzeczenie w singularis. Stąd konkluzja: „Jest rzeczą zadziwiająca, do jakiego stopnia przyjęta a priori koncepcja przedmiotowego «Bytu» może przytępiać spojrzenie tłumacza".

Czytając partie tekstu o traktacie Gorgiasza, dające przenikliwy wgląd w każde prawie jego zdanie, przekonujemy się na każdym kro$\mathrm{ku}$, jak eliminacja sensu egzystencjalnego „bycia” przez wprowadzenie formy predykatywnej uzdrawia treść, czyniąc ją strawną i możliwą do zaakceptowania z logicznego punktu widzenia. Podajmy przykład. W miejsce niezrozumiałego wywodu o „istnieniu”: ,jeżeli coś istnieje, nie istnieje ani jedno, ani mnogość [...], to nie może nic istnieć. Gdyby bowiem coś istniało, to ono byłoby jednym z dwojga", mamy przejrzysty tok rozumowania z predykacją: , „jeżeli rzeczy mają być czymś, a musi być tak, że nie są ani jednym, ani licznym [...], to nie będą żadnym "czymś», bo gdyby czymś były, byłyby czymś innym poza tym, co wymieniono". Nasz uczony, znakomity filolog i filozof, czujący, jak może niewielu, ducha języka greckiego, zauważa z moca, że zaimki ov̉ó́v i $\tau \iota$ żadną miarą nie mogą być traktowane jak podmioty: „nic" i „,coś”, gdyż pełnią zdecydowanie role orzeczników: „,niczym”, ,"czymś”. W tym, co I. Dąmbska tłumaczy: „to, że nic nie istnieje”, chodzi oczywiście nie o istnienie, lecz o to, że nie ma "określonego bycia czymś".

Weźmy inny przykład. Najpierw przekład, w którym nie tylko egzystencjalnie pojmowane jest "bycie”, ale także przedmiotowo „byt", przekład tłumaczki, która jest autorytetem $\mathrm{w}$ dziedzinie logiki: „Jeśli bowiem coś istnieje, to albo jest bytem, albo niebytem, albo [zarazem] jest bytem i niebytem. Ale ani byt nie istnieje - jak pokaże, ani niebyt - jak dowiedzie, ani byt i niebyt, jak też wyłoży; a więc w ogóle nic nie istnieje”. Nie uzdrowi tych bezsensów zastąpienie „istnieje" przez „jest”, jak czynią niektórzy, bo jest to tylko stylistyczny zabieg. Blandzi zauważa: „I znów przypisuje się starożytnemu myślicielowi niedorzeczne stwierdzenie, że «W ogóle nic nie istnieje» (do tego samego sprowadza się «nic nie jest»)". Sam zaś nadaje wypowiedzi Gorgiasza sens, odrzucając przedmiotowy "byt" i egzystencjalne „bycie” przez potraktowanie $\dot{\varepsilon} \sigma \tau \dot{i}$ jako spójki i właściwe operowanie jej orzecznikami, również $w$ formie ov: „Do «jest» mogłoby być odniesione «bycie czymś», «niebycie czymś», lub «bycie i niebycie» łącznie. Tymczasem ani będącym czymś nic nie jest, jak wykaże, ani nie-będącym, co uzasadni, ani [w połączeniu] będącym i nie-będącym, co także wytłumaczy. Nie ma zatem żadnego «czymś»”. Jakże zasadna jest przeto adnotacja: „Biorąc to wszystko pod 
uwagę, należy ciągle wysuwać postulat radykalnych zmian w przekładach starogreckich tekstów filozoficznych".

Dodać należy, że nasz autor przekonująco wykazuje polemiczny charakter wywodów Gorgiasza w stosunku do poglądów głoszonych przez Parmenidesa. Wypowiedzi filozofa z Leontinoj często należy więc interpretować także w sensie werytatywnym. „Wyraża się w nich sceptycyzm co do możliwości oceniania, jak się mają rzeczy naprawdę, tj. stosowania kryterium prawdziwości, ze względu na nieuchwytność ich rzeczywistego stanu, czyli prawdy o nich. «Nic nie jest» (sc. «nie jest czymś»), to tyle co «nic nie jest określone» (= nie ma charakteru istoty, natury), ogólnie: «nic nie jest prawdą». W żadnym wypadku nie chodzi tu o absolutną negację rzeczywistości, czyli jej nieistnienie". Zawiłe wywody oraz dystynkcje pojęciowe Gorgiasza „miały na celu głównie przekreślenie tej zasady poznawczej (kryterium ostatecznego), jaką miał stanowić eleacki «Jednobyt» równoznaczny z Prawdą". „«Nic nie jest» (sc. «bytem») nie oznacza nicości rzeczy, a mówi tylko, że nawet osławiony «Byt» Parmenidejski ( $\pi \alpha \nu \tau \varepsilon \lambda \tilde{\omega} \varsigma$ ov) nie jest takim w rzeczywistości, okazując się poznawczo $\pi \alpha v \tau \varepsilon \lambda \tilde{\omega} \varsigma$ ov̉ó́v".

Predykatywny charakter czasownika eiv $\alpha$ ı wyostrzają jeszcze refleksje nad poglądami Arystotelesa w kwestii „filozofii pierwszej” w rozdziale 1 części II. Otóż wyróżnia tam autor wśród arystotelesowskich zasad wyjaśniających wyjaśnianie istotowe, wywodzące się właśnie z refleksji nad einai jako spójką zdaniową. Przypomina przy tej sposobności słynną formułę Stagiryty to ôv $\tilde{\eta}$ oo $v$, która już jest zwiastunem doniosłego odkrycia, jakiego dokonał u Filona, a o którym będzie mówił w ostatnim rozdziale książki. Podstawowy rodzaj „bycia” wedle Arystotelesa

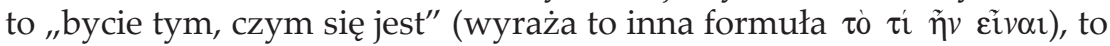
zaś oznacza istotę. Szerzej zajmie się autor związanymi z tym kwestiami w przedostatnim rozdziale książki, przygotowującym ostatni, na temat onto-teologii, zawierający wspomniane odkrycie. Tutaj jednak już nas

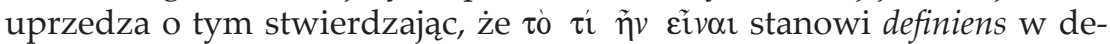
finicji ov̉ ${ }^{\prime} \alpha$ („,istoty rzeczy”), i wyraża „bycie tym, czym się stale jest” w odniesieniu do dowolnego obiektu. Predykatywność istotowego „bycia" widoczna jest jak na dłoni.

W dziele Blandziego najbardziej uderzyło mnie, wpływając nawet $\mathrm{w}$ pewnej mierze na modyfikację moich poglądów, uwydatnienie aspektu werytatywnego i funkcji predykatywnej w greckich wyrażeniach z rodziny Eivou. Z ciekawością jednak śledziłem także, jako filolog i historyk greckiej filozofii, ciąg refleksji etymologicznych, które jak widzę - pasjonują autora. Już w pierwszych rozdziałach zwróciłem uwagę na kilka aluzji na ten temat. Określenie $\alpha \dot{\lambda} \eta \dot{\eta} \varepsilon 1 \alpha$ rozszyfrowuje autor $n p$. jako złożenie $\mathrm{z}$ alpha privativum oraz sufiksu $\lambda \eta \theta$ - związanego z czasownikiem $\lambda \alpha \nu \theta \alpha \dot{v} \varepsilon v$, co wprowadza sens "nie-ukrycia”, czyli

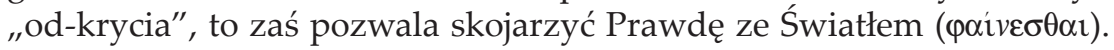


Gdzie indziej znajduję, że greckie oủó́v („nic") etymologicznie oznacza "ani-jedno", wywodzi się bowiem ze zbitki słów ov̉ó i čv. Wyłącznie kwestiom etymologicznym poświęcony jest jednak dopiero rozdział 2 części II. W charakterze wprowadzenia do niezwykle interesujących etymologii Kallimachowych poświęca Blandzi sporo miejsca etymologicznym propozycjom Platona z jego niełatwego w interpretacji Kratylosa. Natomiast po całym bogactwie przykładów z historycznej lingwistyki aleksandryjskiej, a przed prezentacją filozofii światła Pseudo-Dionizego, mamy także Arystotelesową propozycję z dialogu O filozofii wyprowadzenia wyrazu $\sigma o \varphi i \alpha$ z $\sigma \alpha \varphi \eta$ s, i skojarzenia tym samym ze światłem. Tym sposobem tak różnorodna tematyka została zgrabnie powiązana.

Ze względu na rozmiary recenzji trudno kusić się o prezentację zawartości całego dzieła. W tym przypadku wypadałoby stworzyć, na wzór starożytnych komentarzy dzieł klasycznych, obszerny utwór nie mniejszy w objętości od tego, który jest przedmiotem omawiania. Pominę więc godne niewątpliwie bacznej uwagi refleksje nad filozofią światła czy przenikliwe roztrząsanie arystotelesowskiej ousiologii, a także aktualne dziś dyskusje nad problematyką onto-teologii. Niby dwiema klamrami spinają dzieło imiona Parmenidesa i Filona. A zatem jak - wedle autora - „na świadectwie narodzin filozofii widnieje wyraz Prawda równoznaczna z transcendentnym Bytem (Parmenides)", tak - można rzec - na świadectwie narodzin teodycei Filonowe określenie Boga mianem Bytu, którego myślowa samozwrotność rysuje się w pojęciu „bytu jako bytu" arystotelesowskiej formuły.

Profesor Blandzi z całą pewnością nigdy nie wybiera łatwych ścieżek, lecz bierze na warsztat najtrudniejsze teksty (oryginały) antyczne. Z twórczości Platona wybiera nie Fedona np. czy Ucztę, lecz Parmenidesa, Kratylosa, Sofistę, rozczytuje się w Arystotelesowej Metafizyce i Fizyce, następnie w Eneadach Plotyna, bada szeroko twórczość neoplatoników. Nic dziwnego, że to w jego kręgu powstają nowatorskie przekłady i opracowania niełatwej twórczości Heraklita, Parmenidesa, Platona, Arystotelesa, Porfiriusza, Wiktoryna, Boecjusza. Studia takie jak Między aletejologia Parmenidesa a ontoteologia Filona uczą bardzo rzetelnego podejścia do tekstów antycznych.

Osiągnięty w pracy zysk poznawczy, konsekwentnie realizowana metoda historyczno-genetyczna, jest nie tylko dla polskiej nauki niebagatelnej wagi. Chodzi bowiem przede wszystkim o to, że w jednej książce mamy rezultaty pozwalające na ujrzenie $\mathrm{w}$ nowym skorygowanym świetle znacznej części antycznej filozofii greckiej.

Jerzy Wojtczak-Szyszkowski

Uniwersytet Warszawski e-mail: vigil.eo@gmail.com 